\title{
Clear Cell Carcinoma of the Endometrium Causing Paraneoplastic Retinopathy: Case Report and Review of the Literature
}

\author{
Paulina Cybulska, ${ }^{1}$ Eduardo V. Navajas, ${ }^{2}$ Filiberto Altomare, ${ }^{2}$ and Marcus Q. Bernardini ${ }^{3}$ \\ ${ }^{1}$ Department of Obstetrics and Gynecology, University of Toronto, Toronto, ON, Canada M5G 0A3 \\ ${ }^{2}$ Department of Ophthalmology and Vision Sciences, Princess Margaret Hospital, University of Toronto, Toronto, \\ ON, Canada M5G $2 M 9$ \\ ${ }^{3}$ Division of Gynecologic Oncology, Department of Obstetrics and Gynecology, Princess Margaret Hospital, University of Toronto, \\ Toronto, ON, Canada M5G $2 \mathrm{M9}$
}

Correspondence should be addressed to Paulina Cybulska, paulina.cybulska@utoronto.ca

Received 23 May 2011; Accepted 21 June 2011

Academic Editor: J. Higgins

Copyright ( $) 2011$ Paulina Cybulska et al. This is an open access article distributed under the Creative Commons Attribution License, which permits unrestricted use, distribution, and reproduction in any medium, provided the original work is properly cited.

\begin{abstract}
We reviewed the literature for cases in which gynecologic malignancies caused paraneoplastic retinopathy and ultimately led to blindness. Twenty-eight cases were derived from the literature, and one unique case is described from our institution. Of these 28 cases, 14 patients were diagnosed with endometrial cancer, 7 with ovarian cancer, 5 with cervical cancer, 1 fallopian tube cancer and 1 with concomitant endometrial and ovarian cancers. The average age of patients at the time of diagnosis was 64 years (range, 35-89 years). Typically, ocular manifestations antedate symptoms of the underlying carcinoma by 3-12 months. Information regarding the interval from visual symptoms to time of death is limited, but ranges from several months to several years. Our report is the first to document a clear cell carcinoma of the endometrium causing paraneoplastic retinopathy and is the first to review all gynecologic malignancies associated with visual paraneoplastic syndromes.
\end{abstract}

\section{Introduction}

Paraneoplastic syndromes are characterized by remote effects of a cancer that occur at sites distant from the primary tumor or its metastases. Visual paraneoplastic syndromes are rare and are thought to be mediated by an autoimmune process [1]. Corticosteroids and plasmapheresis are the only treatment options previously described. We review the literature of gynecologic cancers causing visual paraneoplastic syndromes and report the first case of clear cell carcinoma of the endometrium causing paraneoplastic retinopathy.

\section{Case Report}

A 62-year-old woman presented with a 1-year history of postmenopausal bleeding. Preoperative MRI revealed less than 50\% myometrial invasion, and she was treated surgically at an affiliated hospital with a total abdominal hysterectomy and left salpingo-oophorectomy. She had previously undergone a right salpingo-oophorectomy. The final pathology revealed a stage 3 clear cell carcinoma with disease penetration to the level of the serosa. Postoperative imaging revealed pelvic and para-aortic lymphadenopathy, and, after discussion at our multidisciplinary rounds, the decision was made to take her back to the operating room for a systematic lymphadenectomy with the hopes of "debulking" and tailoring adjuvant radiation treatment.

She underwent a robotic assisted pelvic and paraaortic lymphadenectomy from which all thirty lymph nodes removed were found to be negative. After her procedure, due to her high-risk features, she received adjuvant chemotherapy with carboplatin and paclitaxel. The intention was that she receives 6 cycles of chemotherapy followed by pelvic and para-aortic radiation. Unfortunately, she displayed ongoing fatigue and had a drop in hemoglobin averaging $20 \mathrm{gm} / \mathrm{L}$ with each treatment resulting in red blood cell transfusion on 
TABLE 1: Reported gynecologic cancers associated with paraneoplastic retinopathy.

\begin{tabular}{|c|c|c|c|c|}
\hline Reference & $\begin{array}{l}\text { Age at } \\
\text { diagnosis }\end{array}$ & Origin of cancer & $\begin{array}{l}\text { Interval between diagnosis } \\
\text { of primary tumor and } \\
\text { onset of visual symptoms } \\
\text { (months) }\end{array}$ & $\begin{array}{l}\text { Interval from visual } \\
\text { symptoms to death } \\
\text { (months) }\end{array}$ \\
\hline$[2]$ & 62 & Endometrioid sarcoma & +5 & 7 \\
\hline$[3]$ & 77 & $\begin{array}{l}\text { Poorly differentiated adenocarcinoma of } \\
\text { the ovary }\end{array}$ & -23 & 23 \\
\hline$[4]$ & 60 & Papillary cystadenocarcinoma of ovary & +7 & NA \\
\hline$[5]$ & 50 & Uterine cancer & +36 & No information \\
\hline$[6]$ & 89 & Poorly differentiated carcinoma of ovary & -15 & 15 \\
\hline$[7]$ & 61 & $\begin{array}{l}\text { Undifferentiated neoplasm of the cervix } \\
\text { uteri }\end{array}$ & -7 & 20 \\
\hline$[8]$ & 64 & $\begin{array}{l}\text { Undifferentiated endometrial } \\
\text { adenocarcinoma }\end{array}$ & $\begin{array}{l}\text { Initial diagnosis: }+8 \\
\text { recurrence: }-3\end{array}$ & 3 \\
\hline \multirow[t]{2}{*}[9]{} & 68 & Carcinoma of the cervix & -3 & 12 \\
\hline & 65 & Serous cystadenocarcinoma of ovary & +24 & Well after 78 months \\
\hline$[10]$ & 63 & Clear cell carcinoma of ovary & -5 & 8 \\
\hline$[11]$ & 72 & Uterine small cell carcinoma & -2 & 6 \\
\hline$[12]$ & 65 & $\begin{array}{l}\text { Malignant mixed mullerian tumor } \\
\text { (homologous) of the endometrium }\end{array}$ & -1 & NA \\
\hline$[13]$ & 77 & Anaplastic uterine carcinoma & +10 & NA \\
\hline$[14]$ & 60 & Endometrial carcinoma & $\begin{array}{l}\text { Initial diagnosis: }-3 \\
\text { recurrence: }-11\end{array}$ & 27 \\
\hline$[15]$ & 67 & Small-cell endometrial carcinoma & +12 & 4 \\
\hline$[16]$ & 35 & Carcinoid tumour of cervix & Article in german & \\
\hline$[17]$ & 60 & $\begin{array}{l}\text { Mixed-type small cell carcinoma of } \\
\text { endometrium }\end{array}$ & $\begin{array}{l}\text { Initial diagnosis: }-4 \\
\quad \text { recurrence: }-18\end{array}$ & 30 \\
\hline$[18]$ & 55 & Clear cell carcinoma of ovary & +27 & 4 \\
\hline$[19]$ & 75 & $\begin{array}{l}\text { Poorly differentiated adenocarcinoma of } \\
\text { the ovary }\end{array}$ & -11 & $\begin{array}{l}\text { Not stated; patient } \\
\text { died after } 6 \text { courses of } \\
\text { chemotherapy }\end{array}$ \\
\hline$[1]$ & 77 & Adenocarcinoma cervix & $-0.5-1$ & NA \\
\hline$[20]$ & 35 & $\begin{array}{l}\text { Serous ovarian cancer and endometrial } \\
\text { carcinoma }\end{array}$ & $\begin{array}{l}\text { Initial diagnosis: }+24 \\
\text { recurrence: }+1\end{array}$ & 6 \\
\hline$[21]$ & 70 & Uterine cancer & +12 & 54 \\
\hline$[22]$ & 58 & $\begin{array}{l}\text { Small cell undifferentiated carcinoma } \\
\text { with minor components of endometroid } \\
\text { and mucinous grade } 1 / 3 \text { of the } \\
\text { endometrium }\end{array}$ & -1 & 2 \\
\hline$[23]$ & 57 & Uterine small cell carcinoma & -1.5 & NA \\
\hline$[24]$ & 66 & Endometrial carcinoma & +4 & NA \\
\hline$[25]$ & 67 & Endometrial carcinoma & Concomitant & NA \\
\hline$[26]$ & 68 & Adenocarcinoma of cervix & -48 & NA \\
\hline$[27]$ & 70 & $\begin{array}{l}\text { Neuroendocrine carcinoma of fallopian } \\
\text { tube }\end{array}$ & -22 & NA \\
\hline Current & 62 & Clear cell carcinoma of the uterus & +8 & NA \\
\hline
\end{tabular}

The interval between diagnosis of the inciting tumor and the diagnosis of retinopathy is listed as positive numbers if the inciting tumor was diagnosed before the diagnosis of retinopathy and as negative numbers if the inciting tumor was diagnosed after the diagnosis of retinopathy.

NA: patient alive at the time of publication.

two occasions. Carboplatin and paclitaxel were both reduced throughout the course of her treatment. Prior to her 4 th cycle, she began to complain about "dimmed vision". CT scans of her chest abdomen and pelvis were repeated at that time. Her previously identified lymphadenopathy had improved, and, due to her overall state, we decided to hold any further chemotherapy. In order to investigate the visual changes, a referral was made to a retinal specialist. 
Ophthalmologic examination revealed best corrected visual acuity of 20/150 in both eyes. Anterior segment examination was unremarkable. Fundoscopy demonstrated multiple confluent oval hypopigmented patches at the level of the retinal pigment epithelium (RPE) and a few pigmented choroidal lesions in the posterior pole in both eyes. Fluorescein angiography revealed areas of transmission hyperfluorescence, and optical coherence tomography showed bilateral serous retinal detachment and areas of RPE loss interspersed with zones of thickened RPE. A diagnosis of cancer-associated nummular loss of the pigment epithelium was made.

The patient was treated systemically with five sessions of plasmapheresis and intravenous immunoglobulin, and locally with bilateral subtenons triamcinolone acetonide injection and an intravitreal triamcinolone acetonide injection in the left eye. Despite treatment, eight months after presentation, vision deteriorated to light perception only in both eyes. She was found to have further loss of RPE, enlargement of one pigmented choroidal lesion, and persistent retinal detachments. Twelve months after presentation cataracts developed as well as iris-pigmented lesions.

Five months after the completion of initial chemotherapy and after investigations and treatment for visual loss, the patient underwent another staging CT scan. This scan showed an increase in the size of the patient's retroperitoneal lymph nodes, and a fine needle aspiration did confirm recurrent metastatic disease 13 months after the initial surgery was performed. After consultation with medical oncology, it was deemed that she would not tolerate conventional chemotherapy nor was she a candidate for clinical trials. She was started on Megace $80 \mathrm{mg}$ twice daily. Unfortunately, she continued to show signs of progressive disease and 21 months after her initial operation was discharged to hospice care.

\section{Discussion}

Bilateral diffuse uveal melanocytic proliferation (BDUMP) is a rare paraneoplastic syndrome, characterized by bilateral vision loss in patients with a systemic carcinoma [24]. Our patient was diagnosed with a rare variant of BDUMP, named cancer-associated nummular loss of the retinal pigment epithelium. It is the only reported case of clear cell adenocarcinoma of the uterus associated with a paraneoplastic syndrome. BDUMP is characterized by uveal tract thickening and degeneration and atrophy of the retinal pigment epithelium [21] and usually does not respond to corticosteroid treatments [24] as was the case with our patient.

There were 28 previously reported cases of gynecologic cancers associated with paraneoplastic retinopathy (Table 1). Of these, 14 patients were diagnosed with endometrial cancer, 7 with ovarian cancer, 5 with cervical cancer, 1 with fallopian tube cancer, and 1 with concomitant endometrial and ovarian cancers. The average age of patients at the time of diagnosis was 64 years (range, 35-89 years). Information regarding the interval from visual symptoms to time of death is limited but can range from several months to several years.
At the time of publication, our patient is alive in hospice care, 16 months after her initial visual complaint, and 21 months after her cancer diagnosis was made.

Paraneoplastic retinopathy has been related to other cancer types, including lung and various GI malignancies (bowel, gallbladder, pancreas). Typically, ocular manifestations antedate symptoms of the underlying carcinoma by $3-12$ months $[9,21]$. However, our patient and the majority of gynecologic cases (15/28) have visual symptoms following the diagnosis of cancer. Classically, patients commonly complain of flickering lights, reduced visual acuity, color impairment and photosensitivity [28]. Our patient complained of "darkness" and visual "dimming."

The onset of visual symptoms during treatment for a gynecologic malignancy should alert the oncologist to a possible cancer-associated retinopathy. A referral to the ophthalmologist is warranted.

\section{References}

[1] J. Guy and N. Aptsiauri, "Treatment of paraneoplastic visual loss with intravenous immunoglobulin: report of 3 cases," Archives of Ophthalmology, vol. 117, no. 4, pp. 471-477, 1999.

[2] R. A. Sawyer, J. B. Selhorst, L. E. Zimmerman, and W. F. Hoyt, "Blindness caused by photoreceptor degeneration as a remote effect of cancer," American Journal of Ophthalmology, vol. 81, no. 5, pp. 606-613, 1976.

[3] C. C. Barr, L. E. Zimmerman, V. T. Curtin, and R. L. Font, "Bilateral diffuse melanocytic uveal tumors associated with systemic malignant neoplasms. A recently recognized syndrome," Archives of Ophthalmology, vol. 100, no. 2, pp. 249-255, 1982.

[4] J. Mullaney, D. Mooney, M. O'Connor, and G. S. A. McDonald, "Bilateral ovarian carcinoma with bilateral uveal melanoma," British Journal of Ophthalmology, vol. 68, no. 4, pp. 261-267, 1984.

[5] S. Tsukahara, K. Wakui, and S. Ohzeki, "Simultaneous bilateral primary diffuse malignant uveal melanoma: case report with pathological examination," British Journal of Ophthalmology, vol. 70, no. 1, pp. 33-38, 1986.

[6] C. E. Margo, P. R. Pavan, D. Gendelman, and E. Gragoudas, "Bilateral melanocytic uveal tumors associated with systemic non-ocular malignancy. Malignant melanomas or benign paraneoplastic syndrome?" Retina, vol. 7, no. 3, pp. 137-141, 1987.

[7] C. E. Thirkill, A. M. Roth, and J. L. Keltner, "Cancer-associated retinopathy," Archives of Ophthalmology, vol. 105, no. 3, pp. 372-375, 1987.

[8] J. W. Crofts, B. N. Bachynski, and J. G. Odel, "Visual paraneoplastic syndrome associated with undifferentiated endometrial carcinoma," Canadian Journal of Ophthalmology, vol. 23, no. 3, pp. 128-132, 1988.

[9] J. D. M. Gass, R. G. Gieser, C. P. Wilkinson, D. E. Beahm, and S. E. Pautler, "Bilateral diffuse uveal melanocytic proliferation in patients with occult carcinoma," Archives of Ophthalmology, vol. 108, no. 4, pp. 527-533, 1990.

[10] A. M. Leys, H. G. Dierick, and R. M. Sciot, "Early lesions of bilateral diffuse melanocytic proliferation," Archives of Ophthalmology, vol. 109, no. 11, pp. 1590-1594, 1991.

[11] E. Campo, M. N. Brunier, and M. J. Merino, "Small cell carcinoma of the endometrium with associated ocular 
paraneoplastic syndrome," Cancer, vol. 69, no. 9, pp. 2283$2288,1992$.

[12] G. H. Eltabbakh, D. L. Hoogerland, and M. C. Kay, "Paraneoplastic retinopathy associated with uterine sarcoma," Gynecologic Oncology, vol. 58, no. 1, pp. 120-123, 1995.

[13] M. A. Murphy, W. M. Hart, and R. J. Olk, "Bilateral diffuse uveal melanocytic proliferation simulating an arteriovenous fistula," Journal of Neuro-Ophthalmology, vol. 17, no. 3, pp. 166-169, 1997.

[14] T. Ohkawa, H. Kawashima, S. Makino et al., "Cancerassociated retinopathy in a patient with endometrial cancer," American Journal of Ophthalmology, vol. 122, no. 5, pp. 740742, 1996.

[15] H. Brink, A. Deutman, and L. Beex, "Unusual retinal pigment epitheliopathy and choroidopathy in carcinomatosis: a rare case of cancer-associated retinopathy," Graefe's Archive for Clinical and Experimental Ophthalmology, vol. 235, no. 1, pp. 59-61, 1997.

[16] F. G. Holz, C. Bellmann, H. Steffen et al., "Carcinomaassociated-retinopathy in the presence of breast carcinoma and a cervical carcinoid tumor," Ophthalmologe, vol. 94, no. 5, pp. 337-342, 1997.

[17] I. Sekiguchi, M. Suzuki, I. Sato, T. Ohkawa, H. Kawashima, and S. Tsuchida, "Rare case of small-cell carcinoma arising from the endometrium with paraneoplastic retinopathy," Gynecologic Oncology, vol. 71, no. 3, pp. 454-457, 1998.

[18] J. T. Donovan, M. Prefontaine, and E. S. Gragoudas, "Blindness as a consequence of a paraneoplastic syndrome in a woman with clear cell carcinoma of the ovary," Gynecologic Oncology, vol. 73, no. 3, pp. 424-429, 1999.

[19] J. P. Harmon, V. A. Purvin, J. Guy, N. Aptsiauri, and G. P. Sutton, "Cancer-associated retinopathy in a patient with advanced epithelial ovarian carcinoma," Gynecologic Oncology, vol. 73, no. 3, pp. 430-432, 1999.

[20] Y. H. Yoon, E. H. Cho, J. Sohn, and C. E. Thirkill, "An unusual type of cancer-associated retinopathy in a patient with ovarian cancer," Korean Journal of Ophthalmology, vol. 13, no. 1, pp. 43-48, 1999.

[21] J. S. Ritland, N. Eide, and J. Tausjø, "Bilateral diffuse uveal melanocytic proliferation and uterine cancer. A case report," Acta Ophthalmologica Scandinavica, vol. 78, pp. 366-368, 2000.

[22] F. Chahud, R. H. Young, J. F. Remulla, J. J. Khadem, and T. P. Dryja, "Bilateral diffuse uveal melanocytic proliferation associated with extraocular cancers: review of a process particularly associated with gynecologic cancers," American Journal of Surgical Pathology, vol. 25, no. 2, pp. 212-218, 2001.

[23] W. Ju, I. A. Park, S. H. Kim, S. E. Lee, and S. C. Kim, "Small cell carcinoma of the uterine corpus manifesting with visual dysfunction," Gynecologic Oncology, vol. 99, no. 2, pp. 504506, 2005.

[24] W. Saito, S. Kase, K. Yoshida et al., "Bilateral diffuse uveal melanocytic proliferation in a patient with cancer-associated retinopathy," American Journal of Ophthalmology, vol. 140, no. 5, pp. 942-945, 2005.

[25] S. Wu, J. S. Slakter, J. A. Shields, and R. F. Spaide, "Cancerassociated nummular loss of the pigment epithelium," American Journal of Ophthalmology, vol. 139, no. 5, pp. 933-935, 2005.

[26] S. Seles and G. E. Lang, "CAR syndrome (carcinomaassociated retinopathy syndrome) associated with an adenocarcinoma of the cervix," Klinische Monatsblatter fur Augenheilkunde, vol. 222, no. 9, pp. 736-739, 2005.
[27] A. Raghunath, G. Adamus, D. C. Bodurka, J. Liu, and J. S. Schiffman, "Cancer-associated retinopathy in neuroendocrine carcinoma of the fallopian tube," Journal of NeuroOphthalmology, vol. 30, no. 3, pp. 252-254, 2010.

[28] C. P. W. Ling and C. Pavesio, "Paraneoplastic syndromes associated with visual loss," Current Opinion in Ophthalmology, vol. 14, no. 6, pp. 426-432, 2003. 


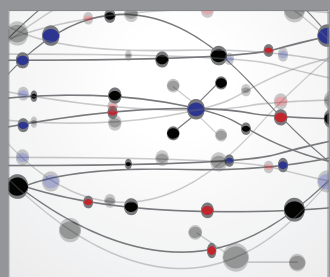

The Scientific World Journal
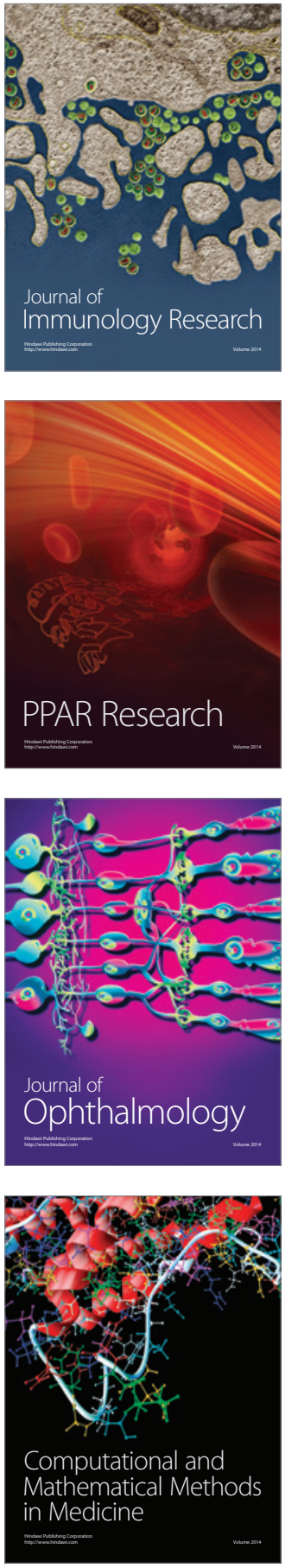

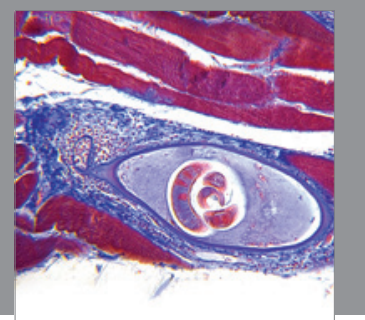

Gastroenterology

Research and Practice
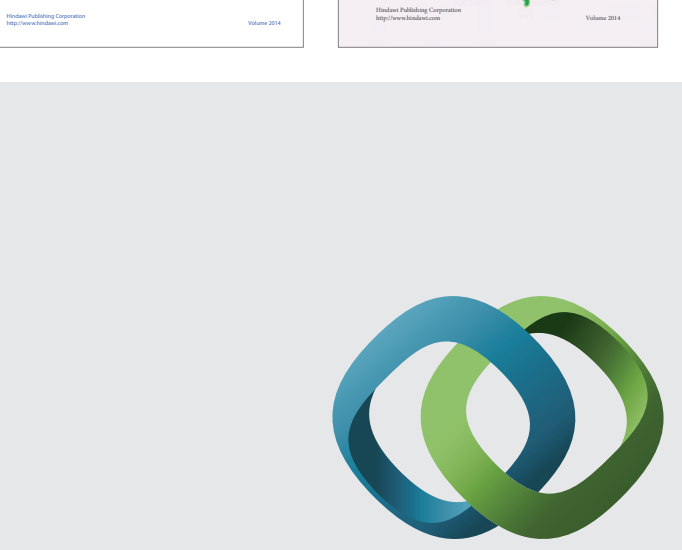

\section{Hindawi}

Submit your manuscripts at

http://www.hindawi.com
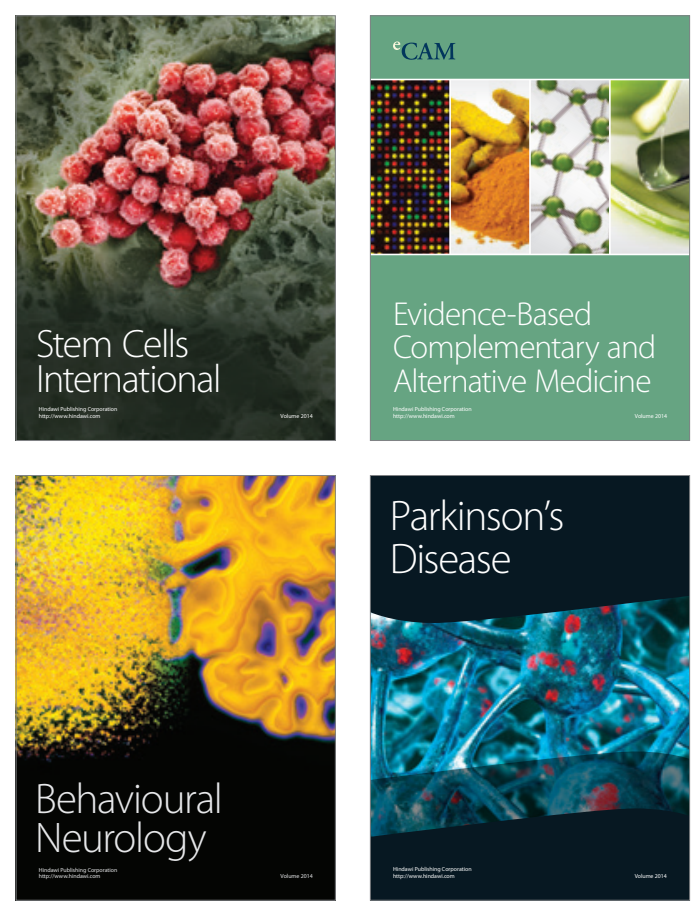

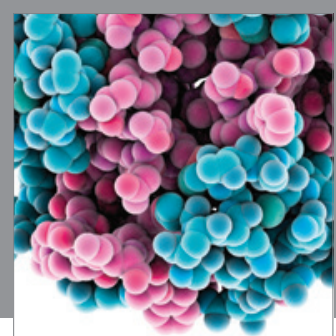

Journal of
Diabetes Research





Disease Markers
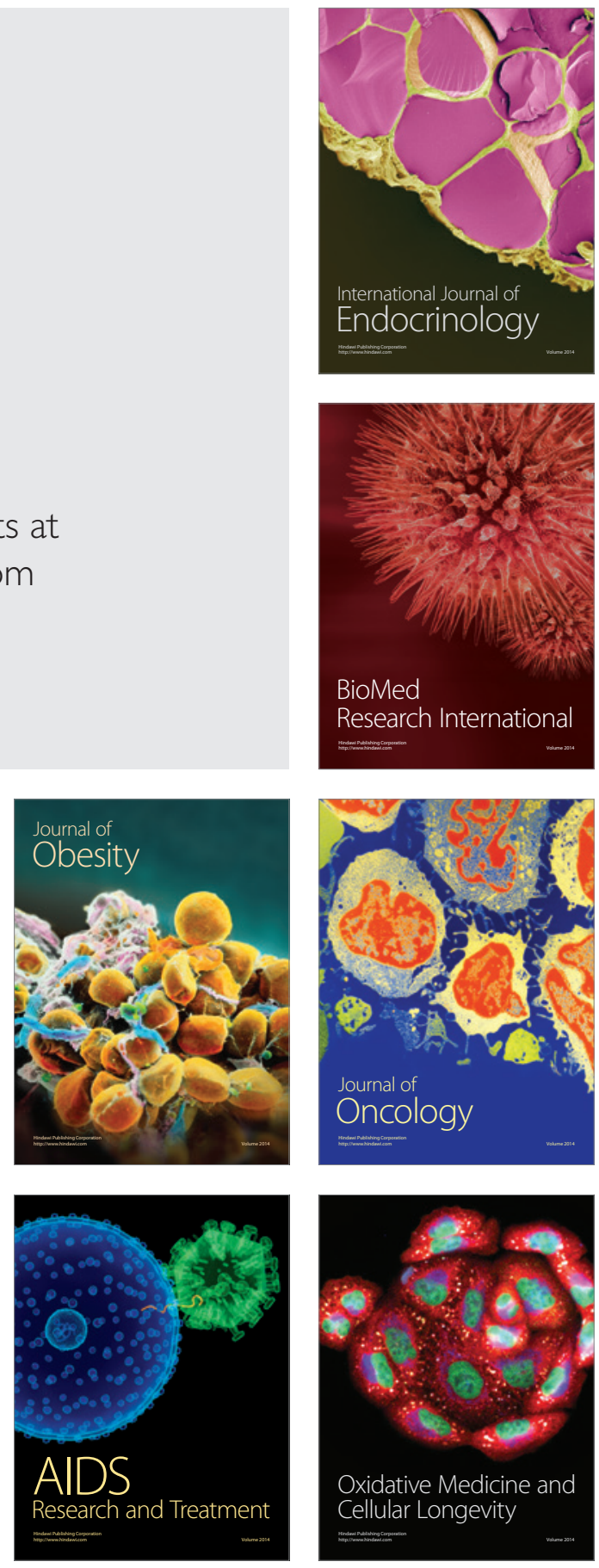